\title{
Pola Pengelolaan Manajemen Zakat BAZ Kota Bandung dalam Mengatasi Kemiskinan
}

\author{
Ridwan Trian Abdullah ${ }^{1 *}$, Dadang Kuswana ${ }^{2}$, \& Yuliani $^{1}$ \\ ${ }^{1} J u r u s a n$ Manajemen Dakwah, Fakultas Dakwah dan Komunikasi, \\ UIN Sunan Gunung Djati, Bandung \\ ${ }^{2} J u r u s a n$ Pengembangan Masyarakat Islam, Fakultas Dakwah dan Komunikasi, \\ UIN Sunan Gunung Djati, Bandung \\ *Email: ridwan.trianabdullab@student.uinsgd.ac.id
}

\begin{abstract}
ABSTRAK
Tulisan ini menjelaskan pola pengelolaan manajemen dakwah dalam mengatasi kemiskinan. Metode penelitian menggunakan metode deskriptif yang melibatkan sumber data dari pengurus Badan Amil Zakat Kota Bandung dan pengumpalan data lapangan. Analisis data dengan analisis kualitatif. Hasil penelitian menunjukkan BAZ Kota Bandung dapat melaksanakan pengelolaan manajemen dengan baik dan tertib. Proses pengelolaan zakat yang dilakukan oleh Badan Amil Zakat (BAZ) Kota Bandung adalah dilakukan secara bertahap dengan metode sosialisasi, edukasi dan advokasi, melalui pendekatan. BAZ Kota Bandung dalam menggerakkan para pengelola agar mengerjakan kegiatan dengan sesuai prosedur, sehingga kegiatan dan tujuan yang telah ditetapkan dapat terlaksana dengan efektif dan efesien dengan cara memberikan pembimbingan, motivasi, perjalinan hubungan dan penyelenggaraan komunikasi. Dalam penerapan konsep pengelolaan manajemen zakat di BAZ Kota Bandung berjalan dengan baik.
\end{abstract}

Kata Kunci: Pola Pengelolaan; Manajemen; Zakat; Kemiskinan

\section{ABSTRACT}

This paper discusses pattern management of da'wah management in overcoming poverty. Research method using descriptive method involving data source from the board of Badan Amil Zakat Kota Bandung and field data. Data analysis with qualitative analysis. The results showed BAZ Kota Bandung can carry out management well and orderly management. The process of zakat management conducted by Badan Amil Zakat (BAZ) Kota Bandung is done gradually with the method of socialization, education and advocacy, through the approach. BAZ Kota Bandung in moving the managers to do activities with appropriate procedures, so that the activities and objectives that have been established can be implemented effectively and efficiently by providing guidance, motivation, relationship relationship and communication implementation. In application of rakat management concept in $B A Z$ Kota Bandung run well.

Keywords: Pattern Management; Zakat Management; Poverty. 


\section{PENDAHULUAN}

Kemiskinan merupakan bahaya besar bagi umat manusia, tidak sedikit umat yang jatuh peradabannya hanya karena kefakiran. Karena itu seperti sabda Nabi yang menyatakan bahwa kefakiran itu mendekati pada kekufuran. Agama Islam telah menawarkan beberapa doktrin bagi manusia yang universal dengan dua ciri dimensi, yaitu kebahagiaan dan kesejahteraan hidup di dunia dan akhirat (Qardawi, 1995 : 12).

Pada awal tahun 2016 Badan Pusat Statistik (BPS) mengumumkan bahwa penduduk yang hidup di bawah garis kemiskinan di Kota Bandung sudah mencapai 304.939 jiwa. Data ini berdasarkan jangka waktu 2013-2018 dari standar kemiskinan ini menurut Badan Pusat Statistik (BPS). Jumlah warga miskin di Bandung ada 304.939 jiwa yang termasuk dalam 79.573 kepala keluarga (KK). Jumlah ini berdasarkan RPJMD 2013-2018. Jumlah warga miskin tersebut dilaporkan setelah pendataan dengan beberapa kriteria masyarakat yang dapat dikatakan miskin.

Hal ini didasarkan pada kriteria BPS, yaitu pendapatan di bawah 600 ribu, hanya membeli satu kaki pakaian saja dalam setahun. Juga lantai rumah yang beralaskan tanah," katanya. Menurut BPS juga menyebutkan jumlah warga miskin menyebar di berbagai wilayah Kota Bandung. Dari 30 kecamatan tiga di antaranya memang memiliki tingkat kemiskinan yang tinggi di banding daerah lain. Di antara beberapa kecamatan yang tingkat kemiskinannya tinggi adalah Babakan Ciparay, Kiara Condong, Jamika dan yang tertinggi yaitu Babakan Ciparay. Hal ini menjadi perhatian khusus di pihaknya bersama SKPD terkait. Pasalnya, tidak menutup kemungkinan warga miskin bertambah sehingga meningkatkan kesenjangan sosial di masyarakat.

Zakat merupakan salah satu dari rukun Islam dan lima nilai instrumental pengentas kemiskinan yang strategis dan berpengaruh pada tingkah laku ekonomi masyarakat sehingga tujuan zakat tidak hanya menyantuni secara konsumtif namun juga memiliki tujuan permanen untuk mengentaskan kemiskinan.

Tujuan zakat baru dapat dipahami dan diyakini apabila di dalam jiwa seseorang telah tumbuh beberapa nilai, seperti keamanan, kemanusian dan keadilan. Oleh karena itu, Al-Qur'an menggunakan kata sedakah sebagai pedoman dari kata zakat tersebut, karena makna sedekah itu sendiri merupakan manisfestasi atas pengguat dan pembenaran yang melahirkan keyakinan, sehingga timbul kesadaran untuk membrikan sebagian dari harta yang disayangi itu dalam bentuk zakat. Hal itu dipandang logis dan wajar bahkan merupakan keharusan. Sebagai sarana pendistribusian harta salah satunya adalah zakat. Dengan zakat harta yang padanya terdapat harta hak orang-orang lain yang harus diberikan, sebagai penyucian dari harta tersebut.

Rencananya Badan Amil Zakat Kota Bandung akan mengalokasikan 30\% dana zakat untuk para fakir dan miskin, meskipun para mustahik (penerima zakat) lainnya tetap mendapatkan alokasi dengan proporsional. Dalam tiga tahun terakhir, Baznas telah mengalokasikan dana zakat ke dalam lima program, yakni 
Bandung Sehat, Bandung Cerdas, Bandung Makmur, Bandung Taqwa, dan Bandung Peduli.

Bandung Sehat adalah program bantuan biaya kesehatan, mulai dari gangguan kesehatan ringan maksudnya masyarakat berpenyakit bisa disembuhkan seperti penyakit kulit, gangguan kesehatan sedang merupakan masyarakat berpenyakit yang relatif bisa dan agak bisa disembuhkan dan memerlukan biaya yang cukup besar seperti ibu melahirkan, dan gangguan kesehatan berat yaitu masyarakat berpenyakit agak sulit disembuhkan dan memerlukan biaya yang lumayan besar. Bandung Sehat juga bekerjasama dengan Kementrian Kesehatan Kota Bandung dengan berbentuk BPJS dengan sasaran masyakarat kurang mampu. Tahun 2016, ada 231 orang penerima manfaat program ini. Sementara itu, Bandung Cerdas adalah bantuan biaya pendidikan bagi siswa SD hingga perguruan tinggi. Tahun lalu, penerima manfaat mencapai 231 orang. Bandung Makmur adalah bantuan modal usaha kecil dengan jumlah penerima manfaat di tahun 2016 sebanyak 182 orang. Ada pula bantuan kepada korban bencana alam, bantuan kepada pegawai non PNS di lingkungan Pemkot Bandung melalui program Bandung Peduli. Tahun 2016 lalu, penerima manfaat Bandung Peduli sejumlah 7.997 orang. Program lainnya adalah Bandung Taqwa, yakni bantuan biaya sarana prasarana keagamaan, bantuan guru mengaji, dan bantuan pembinaan muallaf. Pada tahun 2016 lalu, penerima manfaat program Bandung Peduli sebanyak 165 orang (Humas Pemkot Bandung, 2016).

Namun ditengah-tengah melimpahnya dana dan program yang dicanangkan oleh BAZ Kota Bandung tersebut masih juga terdapat beberapa anggota dari mustahik zakat tersebut yang masih hidup dalam garis kemiskinan dan ada beberapa mustahik yang semestinya mendapat hak mustahik tetapi tidak tersentuh oleh dana BAZ Kota Bandung.

Dalam hal ini penulis mengadakan penelitian yang dilakukan di Badan Amil Zakat Nasional Kota Bandung, Gedung Masjid Agung Al-Ukhuwwah Lt. III Jl. Wastukencana No. 27 Bandung. Di lokasi ini tersedianya data yang dapat dijadikan sebagai objek penelitian. Selain itu, BAZ ini memiliki strategi yang baik dalam melakukan pengelolaan zakat dan salah satu lembaga zakat yang menjadi acuan di Kota Bandung. BAZ Kota Bandung ini terdapat masalah yang relevan dengan bidang garapan dan kajian peneliti sebagai mahasiswa jurusan Manajemen Dakwah khususnya di bidang pengelolaan zakat.

Dari latar belakang masalah tersebut dapat dirumuskan beberapa masalah dengan rumusan masalah: Bagaimana sistem pengelolaan manajemen zakat oleh Badan Amil Zakat Kota Bandung ? Bagaimana strategi pengelolaan manajemen zakat yang dilakukan oleh Badan Amil Zakat dalam mengatasi kemiskinan masyarakat di Kota Bandung?

Metode yang digunakan dalam penelitian ini bersifat deskriptif, penelitian ini fokus mendekripsikan gejala-gejala, masalah-masalah, kejadian dan fakta yang terjadi di BAZ Kota Bandung pada saat sekarang. Metode ini juga bertujuan untuk menggambarkan secara sistematis fakta atau karakteristik mengenai Badan Amil 
Ridwan Trian Abdullah, Dadang Kuswana, \& Yuliani

Zakat Kota Bandung secara factual dan cermat yang berkaitan dengan salah satu aspek manajemen yaitu pengelolaan. Hal ini dimaksudkan untuk menggambarkan, memaparkan, dan menjelaskan data-data informasi tentang pengelolaan dan polapola berbasis manajemen zakat dalam rangka meningkatkan keberlangsungan dakwah melalui observasi, wawancara, dan studi kepustakaan yang menyeruluh terhadap objek penelitian.

Metode ini menjelaskan penelitian fokus tujuannya mendekripsikan gejalagejala, masalah-masalah, kejadian dan fakta yang terjadi pada saat sekarang (Arikunto.S, 2002:30).

Penelitian ini dilakukan dalam rangka melakukan penelaahan terhadap model pola pengelolaan manajemen zakat yang dilakukan pada Badan Amil Zakat Kota Bandung sebagai lembaga amil zakat nasional yang telah memiliki kualifikasi baik. Penelaahan ini terutama meliputi bagaimana BAZ Kota Bandung dapat mengembangkan dan melakukan pola pengelolaan dalam mengatasi kemiskinan.

\section{LANDASAN TEORITIS}

Dalam teori sosiologi, kemiskinan muncul sebagai fakta adanya disorganisasi atau disintegrasi atau kepincangan sosial. Disorganisasi terjadi ketika masyarakat seluruh atau sebagaiannya mengalami ketidaksempurnaan dalam mengorganisasi atau mengintegrasikan tujuan, harapan-harapan, dan aturan-aturan serta tidak menjaga stabilitas atau keseimbangan. Hal ini mungkin terjadi karena perubahan begitu cepat dan orang tidak mampu mengikutinya, sehingga kemungkinan terjadi ketidakseimbangan dalam masyarakat dan orang-orang miskin tetap miskin dan orang kaya tetap kaya. Jika muncul demikian maka jelas yang terjadi dalam kehidupan sosial adalah kekacauan.

Teori yang dijadikan landasan dalam penelitian ini adalah pengelolaan manajemen zakat dalam mengatasi kemiskinan. Dalam kamus besar bahasa Indonesia kontemporer pengelolaan berarti memimpin, mengendalikan, mengatur, dan mengusahakan supaya lebih baik, lebih maju dan sebagainya serta bertanggungjawab atas pekerjaan tertentu (Salim, 2002 : 534).

Dari pemaparan di atas, yang menjadi akar permasalahan kekacauan dalam kehidupan bermasyarakat adalah adanya kekontrasan antara kemiskinan dan kekayaan. Islam tidak melarang umatnya untuk mencari kekayaan sebanyakbanyaknya asalkan ia mampu menjaga kestabilan kondisi sosial (mencegah terjadinya social unrest/keresahan sosial) yakni dengan mendistribusikan kekayaannya kepada orang yang kurang beruntung. Dengan kata lain, di tengah kekayaan yang berhasil dikumpulkannya itu, hendaknya jangan lupa untuk mengeluarkan harta haknya para mustahiq zakat.

Manajemen adalah pekerjaan intelektual yang dilakukan orang dalam hubungannya dengan organisasi bisnis, ekonomi, sosial dan yang lainnya. Secara operasional dan fungsional manajemen zakat dapat dijelaskan secara rinci di antaranya berkaitan dengan perencanaan, pelaksanaan dan pengawasan (Mufraini, 2006 : 28). Manajemen zakat secara operasional dan fungsional sebagaimana 
diungkapkan M Arief Mufraini:

Dalam manajemen zakat proses awal perlu dilakukan perencanaan. Pengelolaan zakat diperlukan pengelola zakat yang profesional, mempunyai kompetensi dan komitmen. Secara konsepsional dan operasional pengawasan adalah suatu upaya sistimatis, untuk menetapkan kinerja setandar pada sistem umpan balik informasi. Hal ini sebagaimana dinyatakan dalam surat At-Taubah ayat 103 :

Ambillah zakat dari sebagian harta mereka, dengan zakat itu kamu membersihkan dan mensucikan mereka dan mendoalah untuk mereka. Sesungguhnya doa kamu itu (menjadi) ketenteraman jiwa bagi mereka. dan Allah Maha mendengar lagi Maha mengetahui (Depag, 2005: 203).

Dalam ayat di atas zakat akan menjadi berkah, tumbuh, berkembang dan bertambah, suci dan beres (baik). Sasaran distribusi zakat disebutkan dalam AlQur'an surat al-Taubah ayat 60. Dalam ayat tersebut ada 8 kelompok sasaran pendistribusian zakat yaitu fakir, miskin, amil, mu'allaf, membebaskan budak (riqāb), orang yang berutang (gharimīn), fì sabīlillah, dan ibn sabīl. Berikut dijelaskan masing-masing dan penafsirannya sesuai dengan konteks sekarang.

Fakir, orang yang tidak mempunyaiharta dan usaha, atau mempunyai harta atau usaha yang kurang dari seperdua kecukupannya, dan tidak ada orang yang berkewajiban memberi belanjanya. kelompok fakir keadaanya lebih kurang beruntung dibanding dengan kelompok miskin.

Miskin, pada umumnya para fuqaha menetapkan kebutuhan pokok hanya dalam tiga hal yaitu pangan, sandang, dan papan, dan kebutuhan tersebut sangat minimalis atau sekedar untuk bertahan hidup. Untuk konteks sekarang, konsep kebutuhan pokok seperti itu jelas perlu penyesuaian. Bukan saja kuantitasnya tetapi juga kualitasnya sehigga dengan kebutuhan pokok tersebut manusia bisa hidup secara wajar (Mas'udi, 1991:. 149).

'Amilīn, dalam literatur-literatur fiqh yang disebut dengan 'āmil zakat adalah imam, khalifah atau amir. Hal ini menunjukkan bahwa yang disebut 'āmil adalah instasi pemerintah yang bertugas secara khusus untuk memungut dan mengelola zakat. Dengan demikian, apabila dikaitkan dengan hak penerimaan dana zakat, yang disebut āmil adalah orang-orang dan atau fungsi-fungsi yang terlibat dalam salah satu dari bidang tanggung jawab sebagai berikut (Mas'udi, 1991: 151):

Muallaf, secara harfiah "muallafati qulūbuhum" dalam surat At-Taubah ayat 60 berarti orang yang sedang dijinakkan artinya. Dengan meminjam ijtihad Umar, pembujukan hati tersebut bukan semata bertujuan agar mereka tetap masuk dalam komunitas Muslim, tetapi lebih agar mereka memilih jalan hidup sesuai dengan jalan hidup kaum Muslim yang sebenarnya, yaitu jalan hidup yang sesuai dengan fitrah manusia.

Riqāb, secara harfiah riqāb adalah orang dengan status budak. Untuk masa sekarang, manusia dengan status budak belian seperti ini sudah tidak ada lagi. Akan tetapi, apabila dilihat maknanya secara lebih dalam arti riqāb merujuk pada kelompok manusia yang tertindas dan dieksploitasi oleh manusia lain, baik secara 
personal maupun struktural. Dengan pengertian ini, dana zakat untuk kategori riqāb dapat digunakan untuk "memerdekakan" orang atau kelompok masyarakat yang sedang dalam keadaan tertindas dan kehilangan haknya untuk menentukan arah hidupnya sendiri. Dengan demikian, dana zakat dapat digunakan untuk membantu buruh-buruh rendahan dan kuli-kuli kasar dari hegemoni majikan mereka dan lain-lain (Mas'udi, 1991: 156).

Gharimīn, secara harfiah "gharimīn" adalah orang-orang yang tertindih hutang. Untuk konteks sekarang, pengertian ini masih relevan. Akan tetapi, di samping penggunaan dana zakat yang bersifat kuratif atau memberikan bantuan setelah terjadinya kebangkrutan atau kepailitan orang yang berutang tersebut, dana zakat seharusnya juga dapat digunakan untuk mencegah terjadinya kebangkrutan tersebut dengan menyuntikkan dana agar usaha seseorang yang terancam bangkrut dapat pulih kembali dan tidak jadi pailit.

F̄̄ sabīlillāh, menurut Masdar F. Mas'udi, istilah "fì sabīlillāh" memiliki dua pengertian. Dalam pengertian negatif, fî sabīlillāh berarti berperang memerangi kekafiran. Sedangkan menurut pengertian positifnya, fî̀ sabīlillāh berarti menegakkan “jalan Allah” itu sendiri (Mas'udi, 1991: 159). Jalan Allah itu diartikan sebagai "cita kebaikan-kebaikan-Nya yang universal, yang mengatasi batas kepercayaan, suku, ras, dan batas-batas formal lainnya." Rinciannya bisa macammacam, tetapi pangkalnya adalah kemaslahatan bersama.

Ibn Sabīl, para fuqaha selama ini mengartikan ibnu sabīl sebagai "musafir yang kehabisan bekal". Meskipun tidak salah dan masih relevan, namun pengertian ini sangat sempit. Untuk konteks sekarang, pengertian ibnu sabīl dapat dikembangkan bukan sekedar pada "pelancong" yang kehabisan bekal, tetapi juga terhadap orang atau kelompok masyarakat yang "terpaksa" menanggung kerugian atau kemalangan ekonomi karena sesuatu yang tidak disengaja seperti karena bencana alam, wabah penyakit, dan peperangan.

\section{HASIL DAN PEMBAHASAN}

Penelitian ini bertempat di Badan Amil Zakat (BAZ) Kota Bandung yang berlokasi di Jalan Wastukencana No.27 Bandung. BAZ ini adalah lembaga pengelola zakat resmi milik pemerintah berbentuk organisasi kemasyarakatan yang pendiriannya melalui SK Walikota tahun 2004 (Struktur organisasi terlampir).

Badan Amil Zakat adalah Lembaga Pengelola Zakat yang dibentuk oleh Pemerintah sesuai dengan tingkatannya dan memiliki hubungan kerja yang bersifat koordinatif, konsultatif dan informatif antara Badan Amil Zakat pada semua tingkatannya. Badan Amil Zakat terdiri dari unsur masyarakat dan pemerintahan yang memenuhi syarat tertentu dan dalam pembentukannya terdiri dari Dewan Pertimbangan, Komisi Pengawas serta Badan Pelaksana dengan tugas mengumpulkan, mendistribusikan, dan mendayagunakan zakat sesuai dengan ketentuan Agama (Syari'ah).

Badan Amil Zakat Nasional (BAZNAS) Kota Bandung telah didirikan pada 
tahun 1981 oleh Pemerintah Daerah Kota Bandung yang berkedudukan di bawah Sekretaris Daerah Kota Bandung dan diketuai langsung oleh Sekretaris Daerah Kota Bandung dengan pengurusnya adalah pegawai Pemerintah Daerah Kota Bandung. Pada awalnya lembaga ini bernama Badan Amil Zakat Infaq dan Shodaqoh (BAZIS) Kota Bandung. Kebijakan serta pokok program penyaluran dana zakat, infaq dan shodaqoh lebih difokuskan kepada fakir miskin dan sabilillah, dengan objek zakat yang paling utama adalah zakat fitrah yang biasa dikeluarkan umat Islam pada bulan Ramadhan saja. Kebijakan program kerja Badan Amil Zakat berdasarkan pada keputusan bersama Menteri Dalam Negeri dan Departemen Agama Nomor 29 Tahun 1991 tentang Pembinaan Badan Amil Zakat Infaq dan Shodaqoh.

Pada tahun 1998 BAZIS Kota Bandung terbentuk dengan masa kepengurusan 1998-2001, namun sejak diberlakukannya undang-undang nomor 38 tahun 1999 tentang pengelolaan zakat, nama BAZIS Kota Bandung diubah menjadi BAZ Kota Bandung pada kepengurusan 2001-2005 BAZIS Kota Bandung berganti menjadi BAZ Kota Bandung sesuai dengan Undang-Undang Nomor : 38 Tahun 1999 tentang Pengelolaan Zakat dan KMA Nomor : 373 Tahun 2003 tentang Pelaksanaan Undang-Undang Nomor 38 Tahun 1999 tentang Pengelolaan Zakat. (Baznas, 2003)

Saat ini BAZ Kota Bandung terdiri dari 4 bidang/seksi yaitu bidang pengumpulan, bidang pendistribusian, bidang pendayagunaan dan bidang pengembangan. Jumlah pengurus yang ada di BAZ adalah sebanyak 42 orang, termasuk di dalamnya 2 orang tenaga Pegawai Negeri Sipil (PNS) Kementrian Agama Pusat yang diperbantukan BAZ Kota Bandung mempunyai muzakki yang sebagian besar adalah Pegawai Negeri Sipil (PNS) di lingkungan pemerintah kota.

Program pemberdayaan kaum dhuafa melalui pemberian bantuan modal usaha, pendamping, pemasaran, pendidikan dan pelatihan keterampiln, serta pembinaan yang sistematis dan berkesinambungan sehingga mereka bisa menjalankan usahanya dengan sebaik-baiknya, dan terwujudnya kemandirian. (Mufraini, M. A. 2006:23)

Dalam upaya mengoptimalkan pengelolaan manajemen zakat, BAZ Kota Bandung menyusun program-program umum, diantaranya: Program Sosialisasi, Advokasi dan Edukasi, Pelaksanaan syari'ah Islam tentang zakat yang bertujuan untuk mewujudkan kesedaraan kolektif bagi ummat Islam dalam menunaika zakat sesuai dengan konsep zakat berdasarkan syari'ah dan ketentuan peraturan yang berlaku berkenaan dengan pengelolaan zakat,

Program Intensifikasi, pengumpulan zakat yang bertujuan untuk meningkatkan penerimaan zakat dengan cara pengelolaan zakat yang profesional berlandaskan syari'ah dan ketentuan peraturan yang berlaku berkenaan dengan pengelolaan zakat, prinsip tata laksana pengelolaan zakat yang baik, diantaranya: akuntabilitas, transparansi, taat azas (syari'ah dan perundang-undangan zakat), dan konsistensi.

Program Ekstensifikasi, bahwa dengan menngkatnya pengumpulan zakat 
seiring pula meningkatnya kesadaran secara kolektif umat islam dalam menunaikan zakat sebagai rukun islam. Dan pada akhirnya semua bentuk dan jenis zakat (zakat emas, perak, uang, perdagangan/perusahaan, hasil pertaniaan, hasil pertambangan, hasil perternakan, hasil pendapatan dan jasa, serta jenis lainnya) sesuai dengan syari'ah islam dan undang-undang yang berlaku, dapat dilaksanakan secara merata dan bertahap di masyarakat muslim melalui lembaga-lembaga baik pemerintahan dan dunia usaha.

Program Pendayagunaan Zakat, program ini dimaksudkan adanya persyaratan, prosedur dan mekanisme kerja agar dalam pendistribusian dana zakat sampai kepada yang menerimanya (Mustahik) berdasarkan syari'ah dan peraturan yang berlaku. Program pendayagunaan dana zakat diantarannya pemberian beasiswa dan pemberian modal usaha. Program Pemberdayaan Mustahiq, program ini dimaksudkan agar mustahiq (penerima hak dana zakat) baik individu maupun lembaga apabila memenuhi syarat asnaf (golongan) maka berhak menerima zakat, diupayakan untuk dapat menjadi insan/lembaga yang sehat, mandiri, dan produktif.

Prinsip umum program ini adalah dalam rangka mengatasi kesenjangan sosial di masyarakat khususnya di bidang ekonomi dan umumnya di bidang lainnya. Program ini juga berupaya untuk keberkahan masyarakat di Kota Bandung. Untuk mencapai tujuan pengelolaan manajemen zakat, BAZ Kota Bandung menyusun program kerja, yaitu:

Bantuan modal usaha, bantuan modal usaha produktif (bergulir), dan life skill kewirausahaan. Bantuan beasiswa SD sederajat, bantuan beasiswa SMP sederajat, bantuan beasiswa SMA sederajat, bantuan PT beasiswa S1, dan bantuan beasiswa luar daerah atau luar negeri. Bantuan biaya kesehatan, penyuluhan kesehatan dan pengobatan gratis sunatan massal. Pembinaan muallaf baru (pembelian al-qur'an, buku2 Islam \& Peralatan Sholat), pengembangan syariat islam (rawan akidah), pembinaan dan reward generasi tahfidz, dan bantuan operasional da'i/guru ngaji/juru merbot. Bantuan kegiatan sosial dakwah, bantuan sarana dan prasarana masjid/pesantren, bantuan panti asuhan islam, bantuan honorer/sukwan SKPD/UPZ, fasilitas umum di lingkungan miskin, bantuan perbaikan rumah tak layak huni, dan kehilangan/kekurangan bekal/ongkos perjalanan.

Hasil penelitian ini menemukan pola pengelolaan manajemen zakat dalam mengatasi kemiskinan di BAZ Kota Bandung. Pola pengelolaan manajemen zakat yang dilakukan BAZ Kota Bandung dalam penerapan fungsi pengelolaan manajemen secara umum dapat dibagi dalam beberapa hal, yaitu:

\section{Sistem Pengelolaan Manajemen Zakat BAZ Kota Bandung}

Dalam pengertian yang paling sederhana, konsep sistem memberikan pada kita pemikiran tentang organisasi. Konsep-konsep tersebut memberikan kerangka acuan menilai akibat pengambilan keputusan manajemen. Kekompleksannya sangat besar apabila manajer tidak berusaha untuk menyederhanakannya. Akan tetapi dengan mengidentifikasi subsistem-subsistemnya (seperti akuntasi, 
produksi, pendidikan, dan lain-lainnya), hubungan diantara subsistem (hubungan horizontal), dan antara subsistem dan sistem (hubungan vertical) di dalam organisasi, seorang manajer dapat mengetahui percabangan dari berbagai macam keputusannya (Darmawan. D, 2013: 51).

Proses pengelolaan zakat yang dilakukan oleh Badan Amil Zakat (BAZ) Kota Bandung adalah dilakukan secara bertahap dengan metode sosialisasi, edukasi dan advokasi, melalui pendekatan: lembaga instansi pemerintahan atau swasta, dewan masjid Indonesia atau pengurus masjid, tokoh islam ulama atau da'i atau ustadz atau mubaligh, dan dunia usaha atau kadin.

Yusuf Al-Qhardawi dalam fiqh zakat mengatakan bahwa pemerintah Islam diperbolehkan membangun pabrik-pabrik atau perusahaan-perusahaan dari uang zakat untuk kemudian kepemilikan dan keuntungannya bagi kepentingan fakir miskin, sehingga akan terpenuhi kebutuhan hidup mereka sepanjang masa. Pengganti pemerintah, untuk saat ini dapat diperankan oleh Badan Amil Zakat atau Lembaga Amil Zakat yang kuat, amanah dan profesional. BAZ atau LAZ jika memberikan zakat yang bersifat produktif harus pula melakukan pembinaan atau pendampingan kepada para mustahik agar kegiatan usahanya dapat berjalan baik (Nawawi. I, 2010:76).

Dilakukan dengan cara pemaparan konsep zakat yang akan diterapkan oleh BAZ Kota Bandung secara dialogis dan tanya jawab, talk show melalui radio swasta, serta penerbitan buletin, disamping itu juga dilakukan melalui kerjasama kemitraan dalam rangka pencapaian tujuan pengelolaan zakat, hasil yang telah dicapai melalui site mini adalah:

Meningkatnya pembentukan Unit Pengumpulan Zakat (UPZ) pada instansi Pemerintahan atau Lembaga sebagai satu kesatuan dari Badan Amal Zakat Kota Bandung yang bertugas melakukan pengumpulan zakat kepada muzzaki secara langsung, Meningkatnya informasi tentang pengelolaan zakat melalui media cetak dan belutin tazkiyah yang diterbitkan oleh BAZ Kota Bandung, dampaknya sangat positif dan menggembirakan yaitu berfungsinya kantor Sekretariat BAZ Kota Bandung sebagai pelayanan pengumpul zakat yang sangat berpengaruh terhadap peningkatan jumlah muzakki serta pemahaman kesadaran berzakat pada masyarakat muslim.

Dalam hal pengumpulan zakat dengan cara peningkatan dan kecepatan (tepat waktu), muzakki yang telah menunaikan zakat melalui, Unit Pengumpul Zakat (UPZ) yang telah dibentuk disetorkan secepatnya ke rekening BAZ Kota Bandung pada Bank Jabar Cabang Bandung. Dalam mencapai tujuan yang telah ditetapkan dalam pengelola manajemen zakat, untuk dapat mengoptimalkan pengumpulan maupun pendayagunaan/pendistribusian, BAZ Kota Bandung perlu menetapkan metode yang akan digunakan dalam pengumpulan dana zakat. Adapun metode yang dilakukan BAZ Kota Bandung dengan cara sosialisasi. Metode ini digunakan agar UPZ yang berada di bawah koordinator BAZ Kota Bandung dapat melaksanakan pengelolaan manajemen dengan baik dan tertib. Sosialisasi yang BAZ Kota Bandung kepada setiap UPZ se-Kota dengan cara 
memberi pengarahan dan penjelasan mengenai pengumpulan, pendistribusian dan pendayagunaan serta mengenai administrasi dana zakat agar dapat mengelola zakat dengan baik.

Menurut bapak Prof. Dr. H. M. Abdurrahman, MA., selaku Ketua BAZ Kota Bandung yang penulis wawancarai, rencananya Badan Amil Zakat Kota Bandung akan mengalokasikan 30\% dana zakat untuk para fakir dan miskin, meskipun para mustahik (penerima zakat) lainnya tetap mendapatkan alokasi dengan proporsional. Dalam tiga tahun terakhir, BAZ telah mengalokasikan dana Zakat ke dalam lima program, yakni Bandung Sehat, Bandung Cerdas, Bandung Makmur, Bandung Taqwa, dan Bandung Peduli. Oleh sebab itu BAZ Kota Bandung mempetakan program kerja menjadi 3 bagian, diantaranya:

Pendistribusian (bantuan zakat untuk program-program sosial karitatif). Bandung Cerdas adalah bantuan biaya pendidikan bagi siswa SD hingga perguruan tinggi. Tahun lalu, penerima manfaat mencapai 231 orang. Bandung Sehat adalah program bantuan biaya kesehatan, mulai dari gangguan kesehatan ringan maksudnya masyarakat berpenyakit bisa disembuhkan seperti penyakit kulit, gangguan kesehatan sedang merupakan masyarakat berpenyakit yang relatif bisa dan agak bisa disembuhkan dan memerlukan biaya yang cukup besar seperti ibu melahirkan, dan gangguan kesehatan berat yaitu masyarakat berpenyakit agak sulit disembuhkan dan memerlukan biaya yang lumayan besar. Bandung Sehat juga bekerjasama dengan Kementrian Kesehatan Kota Bandung dengan berbentuk BPJS dengan sasaran masyakarat kurang mampu. Tahun 2016, ada 231 orang penerima manfaat program bandung sehat. Bandung Peduli kepada korban bencana alam, bantuan kepada pegawai non PNS di lingkungan pemkot bandung melalui program. Tahun 2016 lalu, penerima manfaat bandung peduli sejumlah 7.997 orang.

Dakwah atau advokasi (program dakwah dan pembelaan kepada mustahik). Bandung Taqwa, yakni bantuan biaya sarana prasarana keagamaan, bantuan guru mengaji, dan bantuan pembinaan muallaf. Pada tahun 2016 lalu, penerima manfaat program bandung taqwa sebanyak 165 orang. Pendayagunaan (program bantuan zakat untuk upaya pemberdayaan secara ekonomi). Bandung Makmur adalah bantuan modal usaha kecil dengan jumlah penerima manfaat di tahun 2016 sebanyak 182 orang.

Perlu adanya pendekatan manajemen mengenai administrasi dana zakat agar dapat mengelola zakat dengan baik, jadi BAZ Kota Bandung memberi nominal bantuan berbentuk dan dalam setiap program kerja pendayagunaan bagi para mustahiq, yaitu:

Tabel 1. Nominal Bantuan Bandung Cerdas

\begin{tabular}{ll}
\hline \multicolumn{1}{c}{ Tingkat Bantuan } & Nominal \\
\hline Bantuan Tingkat SD/MI & $\mathrm{Rp}-$
\end{tabular}


Bantuan Tingkat SMP/MTs

Bantuan Tingkat SMA/MA

Bantuan Tingkat S1
Rp -

$\mathrm{Rp}-$

Rp. 2.500 .000

Sumber: Data BAZ Kota Bandung

Tabel 2. Nominal Bantuan Bandung Sehat

\begin{tabular}{|c|c|}
\hline Macam Bantuan & Nominal \\
\hline Bantuan Pengobatan \& Kesehatan & $\begin{array}{l}\text { Rp. } 500.000 \\
\text { Rp. } 750.000 \\
\text { Rp. } 1.000 .000 \\
\text { Rp. } 1.500 .000\end{array}$ \\
\hline $\begin{array}{l}\text { Penyuluhan Kesehatan \& Pengobatan Gratis Khitanan } \\
\text { Masal }\end{array}$ & Rp. 1.500 .000 \\
\hline \multicolumn{2}{|l|}{ Sumber: Data BAZ Kota Bandung } \\
\hline \multicolumn{2}{|c|}{ Tabel 3. Nominal Bantuan Bandung Peduli } \\
\hline Macam Bantuan & Nominal \\
\hline Bantuan paket sembako & Rp. 100.000 \\
\hline Bantuan konsumtif permanen (Jompo) & Rp. 1.000 .000 \\
\hline Bantuan musafir \& terlilit rentenir & Rp. - \\
\hline Bantuan rutin panti asuhan Islam & Rp. - \\
\hline Bantuan Honorer/Sukwan SKPD/UPZ & Rp. 250.000 \\
\hline Bantuan perbaikan rumah tak layak huni & Rp. - \\
\hline Bantuan tanggap bencana (recovery) & Rp. - \\
\hline
\end{tabular}
Sumber: Data BAZ Kota Bandung 
Ridwan Trian Abdullah, Dadang Kuswana, \& Yuliani

Tabel 4. Nominal Bantuan Bandung Takwa

\begin{tabular}{ll}
\hline \multicolumn{1}{c}{ Macam Bantuan } & Nominal \\
\hline Bantuan Guru Ngaii/Marbot & Rp. 300.000 \\
Pembinaan dan reward generasi tahfidz & Rp. 1.000 .000 \\
Bantuan pengembangan syari'at Islam (rawan aqidah) & Rp. - \\
Bantuan muallaf \& Pendampingannya & Rp. - \\
Bantuan sarana ibadah & Rp. 5.000 .000 \\
Bantuan kegiatan keagamaan \& sosial & Rp. 500.000 \\
Rp. 750.000 \\
Rp. 1.000 .000 \\
Rantuan sertifikasi tanah wakaf 1.500 .000
\end{tabular}

Sumber: Data BAZ Kota Bandung

Tabel 5. Nominal Bantuan Bandung Makmur

\begin{tabular}{ll}
\hline Macam Bantuan & Nominal \\
\hline
\end{tabular}

Bantuan modal usaha stimulan dan perbaikan tempat usaha $\quad$ Rp. 1.000 .000 mandiri

Bantuan modal usaha produktif kemitraan/ pemberdayaan Rp. 5.000 .000 (Modal Bergulir)

Pelatihan Life skill kewirausahaan

Rp. -

Sumber: Data BAZ Kota Bandung

Berdasarkan tabel 1-5, Sistem Pengelolaan. Pengelolaan zakat yang dilakukan oleh Badan Amil Zakat (BAZ) Kota Bandung dilakukan secara bertahap dengan metode sosialisasi, edukasi dan advokasi. Dalam mencapai tujuan yang telah ditetapkan dalam pengelola manajemen zakat, untuk dapat mengoptimalkan pengumpulan maupun pendayagunaan/pendistribusian, BAZ Kota Bandung perlu menetapkan metode yang akan digunakan dalam pengumpulan dana zakat.

Diantara indikator keberhasilan pengelolaan zakat adalah para mustahiq dapat mengubah nasibnya sehingga menjadi muzakki, timbulnya kesadaran masyarakat muslim untuk mengeluarkan zakat, terangkatnya kehidupan, derajat, 
dan martabatnya para mustahiq, dan terjadinya hubungan yang erat antara muzakki dengan mustahiq bukan hanya ketika menyalurkan atau memberikan dana zakat, tetapi tetap melakukan hubungan yang sifatnya pembinaan agar dan zakat yang diberikan bukan saja membantu untuk jangka waktu sementara, tetapi diharapkan dengan adanya bantuan dana zakat tersebut mustahiq menjadi lebih mandiri dari pada masa yang akan datang beralih menjadi seorang muzakki. (Budiman, 2008: 15)

\section{Strategi Pengelolaan Manajemen Zakat yang Dilakukan Badan Amil Zakat}

Dalam meningkatkan kinerja pegawai untuk mengoptimalkan pengelolaan manajemen zakat di BAZ Kota Bandung. Maka diambil berbagai keputusan untuk melaksanakan kegiatan untuk meningkatkan kinerja untuk mengoptimalkan pengelolaan. Keputusan itu diambil dalam rapat kerja BAZ Kota Bandung dengan di ikutsertakannya seluruh anggota dalam pengambilan keputusan dan diadaknya komunikasi yang efektif antara pemimpin BAZ dengan para anggotanya serta memberikan motivasi kewenangan kepada para anggota BAZ untuk menjalankan fungsi dan tugas dalam mengelola manajemen zakat pada BAZ Kota Bandung, sekaligus evaluasi kinerja di bulan suci Ramadhan.

Di dalam organisasi di butuhkan adanya pengorbanan yang dilakukan oleh pelaksana untuk melakukan kegiatan-kegiatan dalam rangka mewujudkan tujuan yang telah ditetapkan. Langkah-langkah yang dilakukan oleh BAZ Kota Bandung dalam menggerakkan para pengelola agar mengerjakan kegiatan dengan sesuai prosedur, sehingga kegiatan dan tujuan yang telah ditetapkan dapat terlaksana dengan efektif dan efesien dengan cara memberikan pembimbingan, motivasi, perjalinan hubungan dan penyelenggaraan komunikasi.

Pembimbingan, untuk pencapaian sasaran yang telah ditetapkan maka diperlukan bimbingan atau arahan kepada para pelaksana kegiatan. Sehingga dengan adanya bimbingan atau arahan kepada para pelaksana mengetahui apa yang harus dikerjakan, jalan mana yang harus dituju, kapan melaksanakan tugas, dan kapan harus selesai. Pembimbingan ini dilakukan dengan jalan memberikan perintah atau petunjuk usaha-usaha yang bersifat menetapkn arah dan tindakan mereka. Kegiatan pembimbingan yang dilakukan BAZ Kota Bandung diantaranya dengan cara mengadakan pelatihan-pelatihan tentang Zakat beserta Infak dan Shadaqah kepada BAZ kecamatan, UPZ kelurahan, UPZ DKM dan UPZ Dinas/Instansi, pelatihan manajemen pengumpulan, pelatihan administrasi UPZ DKM sampai kepada UPZ, Dinas/Instansi, mengadakan seminar tentang zakat profesi dan memberikan penjelasan tentang tugas-tugas yang harus dikerjakan oleh para pelaksana agar tidak terjadi kekacauan dalam menjalankan tugas.

Penjalinan Hubungan, untuk menjamin terwujudnya harmonisasi dalam mengelola manajemen zakat, diperlukan adanya hubungan baik diantara pengurus atau pegawai, sehingga dapat mencegah adanya permasalahan internal, tumpang tindih kinerja dan lainnya. Menjalin hubungan yang baik di upayakan oleh BAZ Kota Bandung dalam pengelolaan zakat diantaranya dengan cara rapat internal pengurus, rapat koordiansi insidental, rapat koordinasi dengan UPZ kecamatan 
Ridwan Trian Abdullah, Dadang Kuswana, \& Yuliani

dan UPZ Dinas/Instasi, dan rapat rutina bulanan dalam menetapkan kebijakankebijakan yang sifatnya segera, mengadakan pertemuan-pertemuan dalam merealisasikan bantuan dalam bentuk ceremorial.

Pemberian Motivasi, pemberian motivasi harus dilakukan oleh pimpinan kepada bawahan untuk membangun kepercayaan kepada bawahan atau pegawai. Motivasi yang pertama dan efektif dimulai dari diri sendiri untuk kepercayaan diri sendiri dan orang lain. Keharusan seorang pemimpin mempunyai keyakinan dorongan motivasi kepada bawahan. Dalam memberikan motivasi kepada pengurus dan bawahannya, BAZ Kota Bandung melakukan sebagai berikut, diantaranya:

Mengikutsertakan seluruh pengurus dalam proses pengambilan keputusan. Mengikutsertakan yang dilakukan dengan jalan memberikan kesempatan kepada para pengurus untuk menyampaikan pendapat maupun saran dalam berbagia persoalan,

Memberikan informasi mengenai kinerja. BAZ Kota Bandung menggunakan cara transparansi agar seluruh pengurus mengetahui perolehan yang di dapat oleh BAZ Kota Bandung dan mengetahui pendistribusiannya, itu dijelaskan kepada seluruh pengurus dan pada saat melakukan ekpos realisasi bantuan, BAZ Kota Bandung mengundang seluruh pengurus dan instansi dengan maksud agar segera mengetahui penerimaan yang didapat oleh BAZ Kota Bandung.

Dalam bentuk pendekatan financial, BAZ Kota Bandung menetapkan honor bagi pengurus aktif dan memberi dana transportasi pada pengurus non aktif dalam setiap rapat, memberikan dana operasional kepada setiap bidang. Dalam hal penerapan konsep pengelolaan manajemen zakat di BAZ Kota Bandung berjalan dengan baik. Konsep pengelolaan yang digunakan oleh BAZ Kota Bandung yaitu sesuai dengan pasal 1 ayat (1) UU No. 38 Tahun 1999 meliputi kegiatan, perencanaan, pengorganisasian, pelaksanaan dan pengawasan terhadap pengumpulan dan pendistribusian serta pendayagunaan zakat.

Dengan misi: meningkatkan daya dan hasil guna zakat, infaq, dan shadaqah, meningkatkan pemberdayaan ekonomi umat, meningkatkan sumber daya umat dan meningkatkan kesadaran umat dalam berzakat. Seharusnya dengan misi yang di buat BAZ tersebut diharapkan dapat membantu kinerja pemerintah dalam menangani kemiskinan dan kesenjangan sosial yang ada di Kota Bandung. Namun dengan misi yang dibuat oleh BAZ Kota Bandung dalam praktiknya masih belum optimal karena terdapat beberapa masalah diantaranya kurang sadarnya masyarakat terhadap kewajiban membayar zakat, minimnya dana zakat yang diperoleh dan akhir pendistribusian yang belum optimal.

Dalam sebuah konsep pengelolaan zakat haruslah ada sebuah terobosan baru terkait mengelola zakat agar apa yang diharapkan Badan Amil Zakat bisa terlaksana dengan optimal dan zakat tersebut bisa terus berkembang lalu tidak habis dalam rangka mensejahterakan masyarakat Kota Bandung.

Adapun sistem penerapan yang dilakukan oleh BAZ Kota Bandung adalah 
dengan cara menetapkan standar atau alat ukur, mengadakan pemeriksaan terhadap kinerja atau konsep pengelolaan manajemen zakat dan mengadakan perbandingan antara kegiatan tugas dengan kegiatan nyata dan mengadakan tindakan perbaikan bagi lembaga zakat.

Menetapkan standar (alat ukur), standar yaitu suatu ukuran atau ketentuan yang telah diputuskan bersama dan telah ditentukan oleh BAZ Kota Bandung. Standar digunakan dengan maksud untuk menentukan keberhasilan kegiatan operasional pengelolaan manajemen zakat. Standar juga berguna sebagai alat pembanding dalam penerapan kinerja pengelolaan zakat, alat pengukur untuk mengetahui tentang proses kegiatan pengelolaan manajemen zakat yang telah dilaksanakan, dan alat untuk membantu pembina/ketua dalam mengawasi kegiatan kinerja pengurus.

Mengadakan pemeriksaan terhadap kinerja atau konsep pengelolaan, yang dilakukan oleh BAZ Kota Bandung yaitu dengan cara mengadakan rapat evaluasi yang dilakukan melalui empat langkah diantaranya; Setiap akhir bulan di dalam rapat bulanan, pengurus mengajak semua anggota yang ada untuk mengevaluasi yang telah dilalukan selama satu bulan berlangsung dengan harapan perbaikan kalau perlukan.

Evaluasi empat bulanan, evaluasi tiap semester, kewenangannya di serahkan untuk memberikan evaluasi lebih khusus kepada komisi pengawas untuk melakukan evaluasi terhadap dinamisasi lembaga baik dari perencanaan sampai pada pelaksanaan.

Pada akhir tahun, pengurus bersama-sama bertemu dalam sebuah Rakerda (Rapat Kerja Daerah) dengan mengundang seluruh pengurus yang terdapat dalam struktur lembaga BAZ Kota Bandung. Dalam rapat ini diadakan evaluasi terhadap semua kegiatan dalam satu tahun dengan memberikan kesempatan kepada peserta raker untuk memberikan koreksi-koreksi terhadap berbagai kegiatan yang dilaksanakan dan kalau perlu merevisi berbagai kegiatan yang dipandang perlu direvisi.

Membandingkan antara pelaksanaan kegiatan dengan standar, membandingkan antara pelaksanaan kegiatan dengan standar yang telah ditetapkan untuk mengetahui kesalahan-kesalahan yang terjadi. Cara yang dilakukan pengelola zakat di BAZ Kota Bandung yaitu dengan cara mengadakan evaluasi pada akhir tahun dalam rapat kerja, sebab dalam raker tidak hanya menyusun anggaran tapi juga mengevaluasi kegiatan dalam satu tahun, apakah pengelolaan zakat pada tahun lalu sudah berjalan dengan baik atau berjalan dengan baik tapi kurang memuaskan, atau sama sekali mengalami kegagalan. Dari evaluasi dalam rapat kerja diharapkan dapat diidentifikasikan faktor-faktor yang mendukung dan bisa juga terjadinya faktor-faktor kegagalan, sehingga harus dicari jalan keluarnya untuk memperbaiki yang belum maksimal.

Mengadakan tindakan perbaikan, terakhir jika telah diketahui adanya perbedaan atau kesalahan. Upaya tindak lanjut evaluasi dalam rangka melakukan perbaikan diantaranya dengan cara meminta kepada setiap bidang untuk 
menghimpun sejumlah rencana perbaikan dari setiap bidang termasuk juga ketua diminta mengeluarkan ide dan gagasan untuk melakukan perbaikan.

Jadi, Strategi Pengelolaan. Dalam meningkatkan kinerja pegawai untuk mengoptimalkan pengelolaan manajemen zakat di BAZ Kota Bandung. Langkahlangkah yang dilakukan oleh BAZ Kota Bandung dalam menggerakkan para pengelola agar mengerjakan kegiatan dengan sesuai prosedur, sehingga kegiatan dan tujuan yang telah ditetapkan dapat terlaksana dengan efektif dan efesien dengan cara memberikan pembimbingan, motivasi, perjalinan hubungan dan penyelenggaraan komunikasi. Dalam pengorganisasian terdapat pembagian tugas, wewenang, dan tanggung jawab secara terperinci menurut bidang dan bagianbagian sehingga tercipta hubungan kerja sama yang harmonis dan lancer menuju pencapaian tujuan yang telah ditetapkan (Purwanto, 1990:16).

Beberapa program-program yang dibuat oleh pengurus BAZ Kota Bandung dalam mengatasi kemiskinan di masyarakat bisa dilihat dalam tabel 6 .

Tabel 6. Program Kerja BAZ Kota Bandung

\begin{tabular}{ll}
\hline \multicolumn{1}{c}{ Program } & \multicolumn{1}{c}{ Bentuk Program } \\
\hline Bandung Makmur & Bantuan modal usaha dan modal usaha usaha produktif \\
Bandung Cerdas & Bantuan beasiswa SD, SMP, SMA, S1, dan Luar Negeri \\
Bantuan Sehat & Bantuan biaya kesehatan \\
Bandung Taqwa & $\begin{array}{l}\text { Pembinaan muallaf, tahfidz, da'i, guru ngaji dan pengembangan } \\
\text { Bandung Peduli }\end{array}$ \\
\hline
\end{tabular}

Sumber: Hasil wawancara penelitian

Program kerja yang digunakan oleh BAZ Kota Bandung sebagaimana dalam tabel 1 program kerja BAZ dalam tiga tahun terakhir telah mengalokasikan dana zakat ke dalam lima program tersebut.

\section{PENUTUP}

Temuan penelitian penyelenggaraan ibadah haji di Kanwil Kemenag Provinsi Jawa Barat adalah : Kanwil Kemenag Jabar sebagai leading sector penyelenggara ibadah haji. Kanwil Kemanag Jabar Bidang haji dan Umrah sangat bertanggung jawab atas penyelenggaraan ibadah haji. Dalam meraih kesuskesannya dalam menyelenggarakan ibadah haji, Kanwil Kemenag Jabar memperhatikan tahapantahapan, diantaranya: a) Perencanaan; b) Melakukan pengorganisasian, yaitu pengaturan sumberdaya manusia yang dimiliki oleh Kanwil Kemenag jabar; c) Pelaksanaan pelayanan pada jemaah haji; d) Pengendalian merupakan aktivitas menilai kinerja berdasarkan standar yang telah dibuat untuk kemudian dibuat perubahan atau perbaikan jika diperlukan. 
Mutu kemabruran jemaah haji didasarkan pada perubahan sikap jemaah haji yang lebih baik. Ada beberapa indikator yang ditunjukan oleh jemaah terkait dengan kemabrurannya, yaitu perubahan menuju pada arah yang lebih baik dan jemaah lebih berhati-hati untuk bersikap dalam rangka menjaga kesucian ibadah hajinya.

Dampak alumni haji ditengah masyarkat memiliki dua sudut pandang, yaitu: yaitu: a) Duniawi berdasarkan hubungan langsung manusia, seperti jemaah haji ini selalu berbagi hasil panen ikannya dengan tetangga, membawa cerita yang baru dia dapatkan untuk membangkitkan semangat keislaman masyarakat sekitar, dan selalu memberikan contoh dan teladan yang baik bagi masyarakat. Karena jemaah haji ini lebih disegani setelah kepulangannya, maka ajakan dan seruan dalam kebaikan lebih diperhatikan oleh masyarakat sekitar; b) Ukhrowi berdasarkan hubungan dengan Allah SWT. Seperti peningkatan ibadah kepada Allah, baik ibadah yang wajib seperti shalat 5 waktu tepat waktu dan berjamaah dan ibadah sunnah seperti memperbanyak dzikir dan shalat sunnah.

Temuan penelitian manajemen mutu outcome penyelenggaraan ibadah haji di Kanwil Kemenag Provinsi Jawa Barat menyarankan sebagai berikut: Pertama, Bagi Penyelenggara, Penyelenggara dan juga pemerintahan untuk selalu memberikan pemahaman kepada masyarakat perihal tentang bagaimana menjalani hidup baik yang berkenaan dengan ibadah haji serta dalam menjalankan tugas-tugas keseharian sebagai anggota; Kanwil Kemenag Jabar memberikan pengawasan khusus dan menjalin kerjasama kepada IPHI (Ikatan Persaudaraan Haji Indonesia), supaya lebih efektif dalam mencipatakan ikatan persaudaraan antar jemaah haji; Mempertahankan hubungan yang harmonis dan meningkatkan kualitas pada karyawan sehingga terciptanya kerjasama yang baik dan pelayanan yang memuskan terhadap jemaah haji; Kanwil Kemenag Jabar Bidang Haji dan Umrah harus lebih maksimal dalam merespon keinginan jama'ah dalam setiap pelayanan yang diberikan.

Kedua, bagi alumni jemaah haji, alumni jemaah haji, salah satu kelemahan alumni jemaah haji Indonesia khususnya Wilayah Provinsi Jawa Barat adalah kurangnya kesadaran akan pentingnya sebuah pendidikan agama, sehingga muncul masyarakat lemah kreatifitas, daya pikir, kurang inovatif dan juga lemah dalam memahami kondisi sosial dari zaman ke zaman, hal ini terbukti dengan adanya fakta bahwa alumnu jemaah haji beribadah tanpa tahu dasar hukum dan keilmuannya.

\section{DAFTAR PUSTAKA}

Choliq, Abdul. (2011). Manajemen Haji dan Wisata Religi. Yogyakarta: Mitra Cendika.

Deprez Steff dkk. (2010). Outcome mapping. Denpasar: PT. Cintya

Farid Miftach. (1997). Antar Aku Ketanah Suci: Panduan Haji, Umrah, Ziarah. Jakarta: PT Gema Insani.

Nawawi, Hadari. (2005). Manajemen Strategik. Yogyakarta: Gadjah Mada Pers 
Ridwan Trian Abdullah, Dadang Kuswana, \& Yuliani

Hasibuan, M. S. (2011). Manajemen Dasar, Pengertian, dan Masalah. Jakarta: Bumi Aksara.

Ishikawa, Kaoru. (1992). Pengendalian Mutu Terpadu, PT Remaja Rosdakarya, Bandung.

Kusnawan, A. (2015). Konsep Manajemen Pelatihan Dakwah. Dalam Ilmu Dakwah: Academic Journal For Homiletic Studies, 4(12), 335-370.

Madjid Nur Cholish. (1997). Perjalanan Religius Umrab Dan Haji. Jakarta: PT Temprint.

Safroni, Ladzi. (2012). Manajemen dan Reformasi Pelayanan Publik dalam Konteks Birokrasi Indonesia. Surabaya: Aditya Media Publishing 